\title{
PENGUJIAN DAYA DUKUNG LAPIS TANAH DASAR (SUBGRADE) PADA TANAH TIMBUNAN UNTUK LAPISAN JALAN DENGAN ALAT DCP (DYNAMIC CONE PENETROMETER)
}

\author{
Tatang Sumarna \\ Staf Pengajar Jurusan Teknik Sipil Politeknik Negeri Bandung Jl. Gegerkalong Hilir Ds.Ciwaruga \\ Bandung 40012. Email: tatang.sumarna2@gmail.com
}

\begin{abstract}
ABSTRAK
Jalan merupakan prasarana transportasi yang paling banyak digunakan oleh masyarakat Indonesia untuk melakukan mobilitas keseharian sehingga volume kendaraan yang melewati suatu ruas jalan mempengaruhi kapasitas dan kemampuan dukungnya. Kekuatan dan keawetan kontruksi perkerasan jalan sangat ditentukan oleh sifat-sifat daya dukung tanah dasar. Pengujian dilakukan dengan Calfornia Bearing Ratio (CBR) rendaman untuk bahan tanah timbunan, dan dengan Dynamic Cone Penetrometer (DCP) untuk prototipe subgrade jalan. Nilai CBR akan berbeda-beda sesuai dengan kedalaman lapisan yang diuji. Pada kedalaman 0-340 mm, 340-590 mm dan kedalaman 590-950 mm berturut-turut diperoleh nilai CBR rata-rata sebesar 7.62\%, 19.67\% dan $21.90 \%$, lebih besar dari nilai CBR rencana yaitu 5.7\%. Hal ini berarti subgrade memenuhi syarat kekuatan.
\end{abstract}

Kata kunci: jalan, california bearing ratio, dynamic cone penetrometer

\section{Pendahuluan}

Jalan merupakan prasarana transportasi yang paling banyak digunakan oleh masyarakat Indonesia untuk melakukan mobilitas keseharian sehingga volume kendaraan yang melewati suatu ruas jalan mempengaruhi kapasitas dan kemampuan dukungnya. Kekuatan dan keawetan kontruksi perkerasan jalan sangat ditentukan oleh sifat-sifat daya dukung tanah dasar (Sukirman 1999).

Konstruksi perkerasan lentur jalan terdiri dari lapisan-lapisan yang diletakkan di atas tanah dasar yang telah dipadatkan. Lapisan-lapisan tersebut berfungsi untuk menerima beban lalu lintas dan menyebarkan ke lapisan di bawahnya. Beban kendaraan dilimpahkan ke perkerasan jalan melalui bidang kontak roda beban berupa beban terbagi rata. Beban tersebut berfungsi untuk diterima oleh lapisan permukaan dan disebarkan ke tanah dasarmenjadi lebih kecil dari daya dukung tanah dasar (Sukirman 1999).

Tanah dasar (Subgrade) adalah permukaan tanah semula, permukaan tanah galian atau timbunan yang dipadatkan dan merupakan dasar untuk perletakan bagian lapis keras lainnya, oleh karena itu penelitian terhadap tanah dasar (Subgrade) perlu ditingkatkan.

\section{II.Studi Pustaka}

Tanah merupakan komponen utama subgrade yang memiliki karakteristik, macam, dan keadaan yang berbeda-beda, sehingga setiap jenis tanah memiliki kekhasan perilaku. Sifat tanah dasar mempengaruhi ketahanan lapisan di atasnya (Sukirman 1999).

Masalah-masalah yang dihadapi dalam tanah dasar merupakan masalah yang sudah umum dijumpai selama proses pekerjaannya. Adapun masalah-masalah yang sering dijumpai pada pekerjaan tanah dasar (Sukirman 1999) adalah sebagai berikut.

1. Perubahan bentuk tetap, yaitu perubahan bentuk akibat beban lalu lintas. Perubahan bentuk yang besar akan mengakibatkan jalan tersebut rusak.

2. Sifat mengambang dan menyusut dari tanah, yaitu perubahan yang terjadi akibat perubahan kadar air yang didukung tanah tersebut.

3. Perubahan bentuk karena daya dukung tanah yang tidak merata dan sukar ditentukan secara pasti pada daerah dan macam tanah yang mempunyai sifat dan kedudukan yang berbeda.

4. Perubahan bentuk akibat terjadinya lendutan dan pengembangan kenyal yang 
besar selama dan sesudah pembebanan lalu lintas dari macam tanah tertentu.

5. Perubahan bentuk akibat dilakukannya tambahan pemadatan, karena terjadinya penurunan oleh beban tanah dasar tidak dipadatkan secara baik, dimana daya dukung tidak optimal.

Untuk memperkecil terjadinya masalah yang menyangkut tanah dasar seperti di atas, maka langkah yang harus dilakukan adalah melakukan pekerjaan tanah dasar sesuai dengan peraturan pelaksanaan pembangunan jalan raya yang berlaku. Peraturan pelaksanaan yang menyangkut penyelidikan lokasi mengenai faktor kadar air tanah, material tanah, keadaan dan klasifikasi tanah dan sifat penting tanah serta daya dukung tanah. Tanah yang kurang memenuhi persyaratan untuk dijadikan sebagai lapisan tanah dasar, maka perlu dilakukan peningkatan daya dukung tanah dengan melakukan perbaikan terhadap tanah tersebut. Adapun cara yang dilakukan untuk meningkatkan daya dukung tanah tersebut (Sukirman 1999) dengan cara:

1. Cara dinamis, cara perbaikan tanah dasar dengan menggunakan alat-alat berat seperti compactor yang dilengkapi dengan alat penggetar untuk pekerjaan pemadatan.

2. Memperbaiki gradasi yang ada, cara ini dilakukan dengan menambah fraksi yang kurang kemudian dicampur dan dipadatkan.

3. Dengan stabilitas kimia, cara ini dilakukan dengan menstabilitaskan lapisan tanah dasar dengan bahan-bahan kimia seperti semen portland, kapur, dan bahan kimia lainnya.

4. Membongkar dan mengganti, langkah ini dilaksanakan apabila tanah dasarnya sangat jelek dan mengganti tanah aslinya dengan material yang lebih baik, berkualitas tinggi, dan mempunyai daya dukung yang optimal.

Menurut Terzaghi dan Peck (1987) tingkat pemadatan tertinggi diperoleh apabila kadar air mempunyai suatu nilai tertentu yang disebut kadar air kelembaban optimum (optimum moisture content) dan prosedur untuk mempertahankan agar kadar air mendekati nilai optimumnya selama pemadatan timbunan dikenal sebagai kontrol kadar kelembaban (moisture content control).
Bowles (1991) mendefinisikan empat variable pemadatan tanah yaitu :

1. Usaha pemadatan (energi pemadatan)

2. Jenis tanah (gradasi, kohesif atau tidak kohesif, ukuran partikel, dsb-nya)

3. Kadar air Berat isi kering (Proctor menggunakan angka pori)

Karena volume tanah terdiri dari bagian padat dan kekosongan diantaranya (voids), maka tekanan akan menurunkan kekosongan (void ratio) tiap satuan tekanan atau beban. Rasio kekosongan menyatakan perbandingan volume kekosongan dengan volume padatan (Baver 1962).

Dalam uji tumbukan maupun uji remasan, beberapa contoh tanah dicampur dengan jumlah air yang makin bertambah banyak, dipadatkan di dalam cetakan, dan ditimbang. Apabila diketahui berat tanah basah di dalam cetakan yang volumenya diketahui maka berat isi tanah basah $(\gamma b)$ dapat langsung dihitung berat tanah basah di dalam cetakan per volume cetakan. Kemudian berat berat isi kering ( $\left.\gamma_{\text {kering }}\right)$ dalam satuan $\left(\mathrm{g} / \mathrm{cm}^{3}\right)$ dapatdihitung sebagai berikut:

$$
\gamma_{\text {kering }}=\frac{\gamma_{\text {basah }}}{1+\frac{w(\%)}{100}}
$$

dimana $\mathrm{w}(\%)$ sama dengan persen kadar air, pada rumus di atas adalah kadar air setelah dipadatkan. Dari data beberapa contoh yang dipadatkan dipakai untuk menggambarkan kurva berat isi kering terhadap kadar air (Bowles 1991).

Menurut Gill dan Van den Berg (1967) pemadatan tanah adalah sifat dinamik tanah dimana tingkat kepadatan naik. Dalam hal ini pengeringan dan pengerutan dapat juga meningkatkan kepadatan tanah selain gayagaya mekanis yang bekerja pada tanah.

Pada umumnya perencanaan jalan di Indonesia khususnya di lingkungan Departemen Pekerjaan Umum menggunakan nilai CBR (California Bearing Ratio) dalam menentukan tebal perkerasan berdasarkan proyeksi lalu lintas dan umur rencananya. Data CBR dapat digunakan untuk mengevaluasi perlunya pemeliharaan dan peningkatan jalan. Dalam usaha mendapatkan data CBR di lapangan, dapat dilakukan penentuan nilai CBR di tempat (in situ) secara konvensional (SNI 03-1738- 
1989), namun cara ini memerlukan waktu yang relatif lama dan peralatan CBR laboratorium yang relatif mahal (SNI 03-1744-1089). Cara lain yang relatif baru tetapi sudah diterapkan di lapangan adalah dengan alat Dynamic Cone Penetrometer (DCP). Alat DCP pada Gambar 5 terdiri dari bagian tangkai baja yang dibagian ujung dipasang konus baja dengan ukuran dan bentuk tertentu, dan di bagian atas dilengkapi dengan batang pengarah jatuh palu penumbuk. Metode DCP ini adalah cara pengujian perkerasan jalan (tanah dasar /subgrade, pondasi bahan berbutir) yang relatif cepat, yaitu dengan masuknya ujung konus ke dalam tanah yang ditimbulkan oleh pukulan palu dengan beban dan tinggi jatuh tertentu menerus sampai kedalaman tertentu pula. Untuk memperkirakan nilai CBR tanah atau bahan granular dapat menggunakan beberapa metode, namun yang cukup akurat dan paling murah saat ini adalah menggunakan DCP. Disamping itu DCP adalah salah satu pengujian tanpa merusak atau Non Destructive Testing (NDT), yang digunakan untuk lapis pondasi batu pecah, pondasi bawah sirtu, stabilitas tanah dengan semen atau kapur dan tanah dasar.

Transport Road Research (TRL 1993) mengembangkan prosedur pengujian lapis perkerasan dengan DCP, dan dilaporkan dalam Overseas RoadNote 31 (1993) menggunakan hubungan sebagai berikut :

Van Vuuren, 1969, (Konus $\left.60^{\circ}\right)$ :

$\log \mathrm{CBR}=2,632-1,28(\log \mathrm{DCP})$

Kleyn \& Haden, 1983, (Konus $\left.30^{\circ}\right)$ :

$\log$ CBR $=2,555-1,145(\log$ DCP)

Smith \& Pratt, 1983, (Konus $\left.30^{\circ}\right)$ :

$\log C B R=2,503-1,15(\log \mathrm{DCP})$

TRL, Road Note 8, 1990,(Konus $\left.60^{\circ}\right)$ :

$\log \mathrm{CBR}=2,48-1,057(\log \mathrm{DCP})$

Pada Gambar 1 ditampilkan hasil pengujian DCP dan CBR, serta korelasi antara DCP dengan CBR.

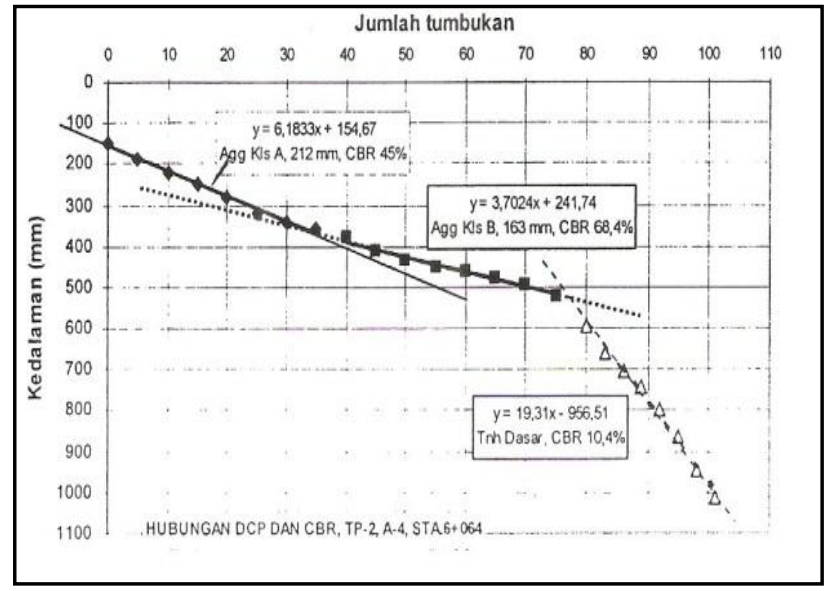

Gambar 1. Contoh grafik hasil pengujian DCP dan CBR (Dahlan, 2005)

\section{Metodologi}

Penelitian dilakukan di lahan pertanian milik Institut Pertanian Bogor di Desa Cikarawang Bogor, sedangkan pengujian karakteristik tanah dilakukan di Laboratorium Fisika dan Mekanika Tanah, Institut Pertanian Bogor. Peralatan yang digunakan dalam penelitian ini adalah: 1). pengambil contoh tanah. 2). pengukur kadar air. 3). pengukur berat jenis. 4). saringan pengukur butir tanah. 5). penguji konsistensi tanah. 6). pengujian kompaksi/proktor standar . 7). penguji California Bearing Ratio (CBR). 8). Dynamic Cone Penetrometer (DCP).

Alat pemadatan tanah timbunan yang digunakan pada proses pembuatan prototipe jalan usahatani di lapangan adalah Model Tamping RammerMT $75 \mathrm{H}$.

Penelitian ini dibuat prototipe subgrade jalan dari tanah timbunan yang berasal dari lokasi yang sama.

\section{Analisis dan Pembahasan}

Pengambilan contoh tanah untuk pengujian ini pada kedalaman $0-110 \mathrm{~cm}$. Nilai CBR rendaman yang diperoleh adalah $5.7 \%$. CBR rendaman (soaked) yang dilakukan di laboratorium adalah kondisi yang sering dialami di lapangan. Dalam perhitungan konstruksi bangunan yang dipergunakan sebagai dasar perhitungan adalah nilai CBR rendaman, karena dalam kenyataannya air selalu mempengaruhi konstruksi jalan. 
Tanah timbunan untuk tanah dasar atau subgrade diperoleh sekitar daerah percobaan pembuatan prototipe jalan usahatani yang telah diambil contoh tanahnya. Tanah timbunan untuk tanah dasar jalan. Pembuatan prototype subgrade jalan denagan cara:

1. Persiapan bahan, peralatan dan tenaga kerja.

2. Pembuatan profil melintang jalan dengan penimbunan awal, tebal penimbunan untuk setiap lapis pemadatan adalah sekitar 20 $\mathrm{cm}$, seperti terlihat pada Gambar 2.

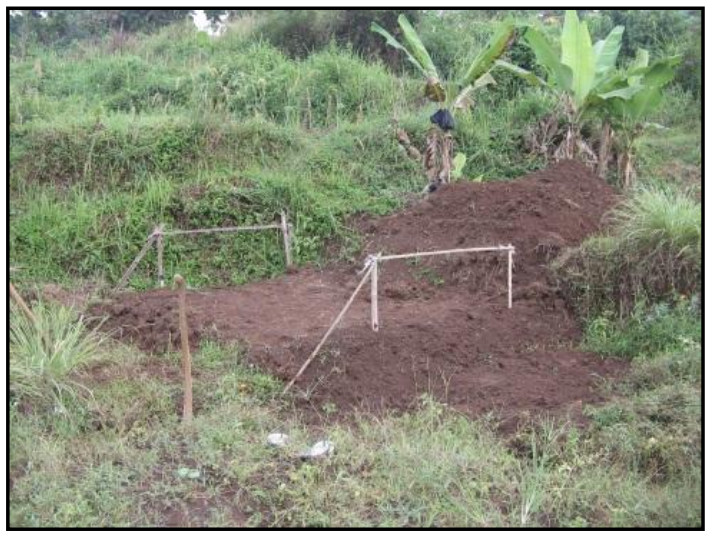

Gambar 2. Pembuatan profil melintang jalan dengan penimbunan awal

3. Koreksi kadar air tanah bahan timbunan di lapangan dengan cara mengetahui batas plastisnya, yaitu menggulung beberapa bahan tanah timbunan dengan jari tangan menjadi diameter $\pm 3 \mathrm{~mm}$, dimana pada diameter tersebut tanah mulai retak. Dari beberapa bahan timbunan yang ada, sebagian ada yang mencapai batas plastis dan sebagian lagi tidak mencapai batas plastis. Penyelesaiannya tanah bahan urugan yang kekurangan kadar airnya ditambah dengan cara disiram sampai mendekati batas plastis. Pelaksanaan koreksi batas plastis.

4. Selanjutnya yaitu pelaksanaan pemadatan lapis pertama, dimana tebal setiap lapis tanah timbunan yaitu $20 \mathrm{~cm}$. Alur pemadatan tanah timbunan yaitu berbentuk seperti spiral yang dimulai dari sisi tanah timbunan menuju pusat timbunan, dan dari pusat timbunan menuju sisi timbunan, seperti terlihat pada Gambar 3.

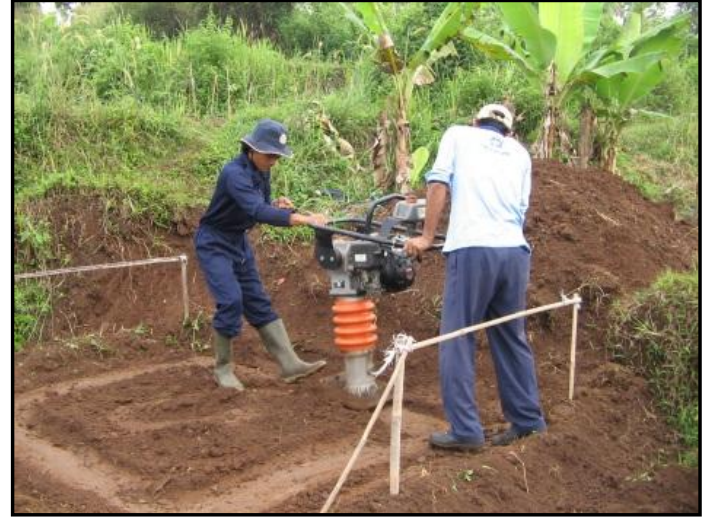

Gambar 3. Bentuk alur pemadatan dari sisi menuju pusat

Mengacu pada pekerjaan tanah dasar pada buku Departemen Pekerjaan Umum Direktorat Bina Marga No : 003-01/BM/2006 pada halaman 74100 tentang tebal dan jumlah lapisan pemadatan. Untuk tebal tanah kohesif tebal lapisan berkisar antara 10 sampai $20 \mathrm{~cm}$, sedangkan jumlah lintasan berkisar antara 4 sampai 8 lintasan. Dalam percobaan pembuatan prototipe ini pemadatan dilakukan 5 lintasan. Gambar 4 merupakan hasil dari pemadatan akhir lapisan pertama

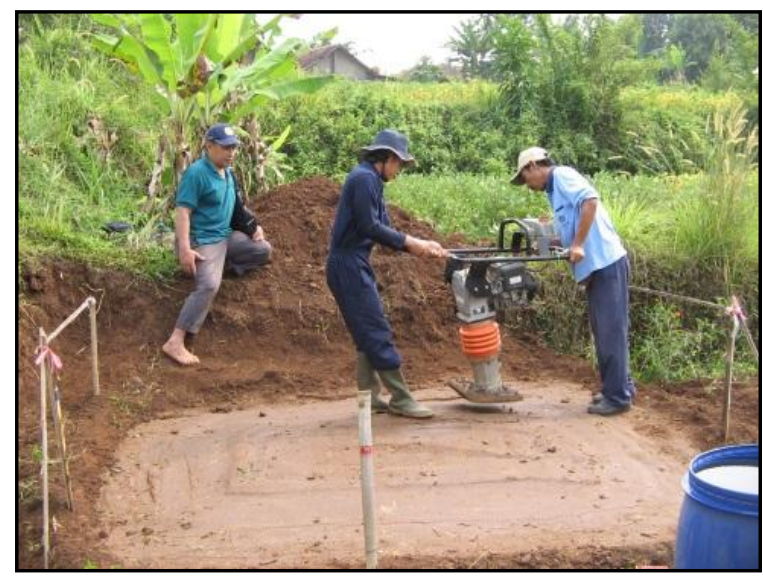

Gambar 4. Pemadatan akhir lapis pertama

Pengamatan dalam proses pemadatan pada lapis pertama yaitu dari tebal tanah timbunan kondisi gembur adalah $20 \mathrm{~cm}$ menghasilkan tanah dalam kondisi padat yaitu rata-rata 12 $\mathrm{cm}$. Hasil pengamatan satu titik pemadatan tanah adalah 3-5 tumbukan.

5. Untuk lapis kedua sampai lapis terakhir tahapannya sama dengan urutan lapis pertama, dimana jumlah lapisan yang dipadatkan adalah 8 lapisan. Lapisan terakhir hasil pemadatan seperti pada Gambar 5. 


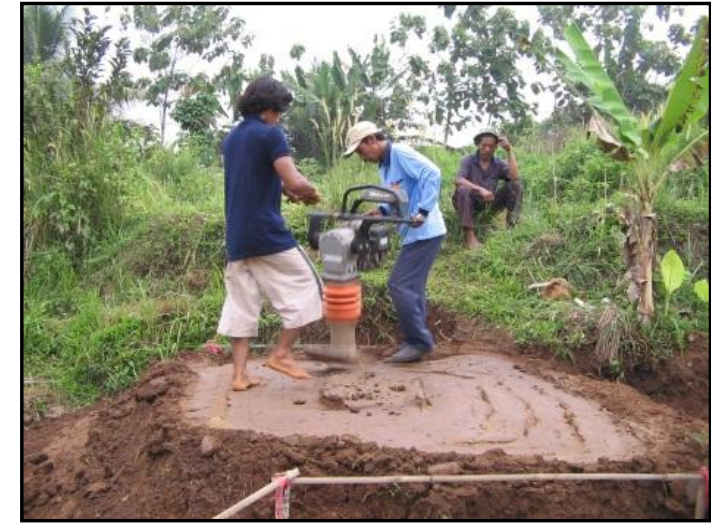

Gambar 5. Pemadatan akhir lapis terakhir

6. Setelah lapis terakhir selesai, maka langkah selanjutnya pengambilan data DCP (Dynamic Cone Penetrometer) sebanyak 2 titik pada lokasi yang berbeda. Maksud pengambilan data DCP (Dynamic Cone Penetrometer) yaitu untuk mengetahui nilai CBR (California Bearing Ratio) yang ada dilapangan, dan data CBR (California Bearing Ratio) yang diperoleh dilapangan akan dijadikan CBR rencana untuk tebal perkerasan jalan usahatani yang ada di atasnya. Gambar 6 merupakan salah satu contoh pengambilan data DCP (Dynamic Cone Penetrometer) di satu titik.

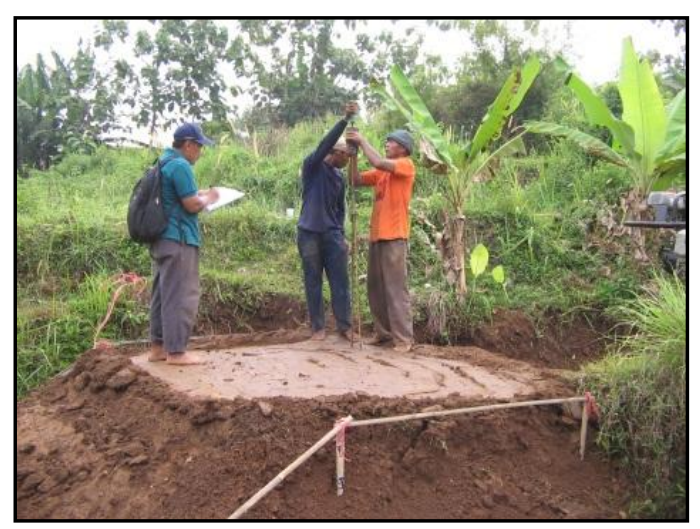

Gambar 6. Pengambilan data DCP

Perhitungan pengujian kekuatan tanah dasar (subgrade) prototipe jalan usahatani menggunakan alat DCP (Dynamic Cone Penetrometer). Pada Tabel 1 disajikan nilai rata-rata CBR (California Bearing Ratio) dari tiap bagian kedalaman.
Tabel 1 Nilai rata-rata CBR (California Bearing Ratio) dari tiap bagian kedalaman.

\begin{tabular}{ccc}
\hline Lapisan & $\begin{array}{c}\text { Kedalaman } \\
\text { rata-rata } \\
(\mathrm{mm})\end{array}$ & $\begin{array}{c}\text { Rata-rata CBR } \\
\text { tiap kedalaman } \\
(\%)\end{array}$ \\
\hline Bagian A & $0-340$ & 7.62 \\
\hline Bagian B & $340-590$ & 19.67 \\
\hline Bagian C & $590-950$ & 21.91 \\
\hline
\end{tabular}

Dengan mengacu pada Tabel 1 nilai rata-rata CBR yang diperoleh sebesar 7.62\%, 19.67\% dan $21.91 \%$, yang lebih besar dari CBR rencana yaitu $5.7 \%$. Hal ini berarti CBR subgrade memenuhi syarat kekuatan.

\section{Kesimpulan}

Kekuatan prototipe subgrade jalan usahatani mempunyai nilai CaliforniaBearing Ratio (CBR) yang merupakan korelasi dari nilai Dynamic Cone Penetrometer (DCP), dimana pada kedalaman 0-340 $\mathrm{mm}, 340-590 \mathrm{~mm}$ dan 590-950 mm berturut-turut diperoleh nilai CBR rata-rata sebesar $7.62 \%, 19.67 \%, 21.91 \%$. Nilai CBR tersebut lebih besar dari nilai CBR rencana yaitu $5.7 \%$. Hal ini berarti subgrade memenuhi syarat kekuatan

\section{Daftar Pustaka}

Baver, LD. (1962): Soil Physic. John Willey and Son,Inc., New York.

Bina Marga. (1974): Penentuan tebal perkerasan (flexible) (A guide for pavementdesign) (flexible).

Direktorat Jenderal Bina Marga No.04/PD/BM/1974

Bina Marga. (2005): Peraturan perentjanaan geometrik jalan raja (standardspecification for geometric design of rural highways). Direktorat JenderalBina Marga R.SNI T 02 -2005.

Bowles, J.E.(1991): Sifat-sifat Fisis dan Geoteknik Tanah oleh Hainim J.K Edisi 2. Erlangga. Jakarta

Dahlan, AT.(2000): Laporan Petunjuk Pengoperasian Penetrasi Konus Dinamis. Pusat Litbang Prasarana Transportasi Bandung.

Dahlan, AT (2005): Jurnal Standarisasi Vol. 7 No.3. 
Das BM, dan Mochtar, NE. (1998): Mekanika Tanah (prinsif-prinsif rekayasa Geoteknik). Erlangga. Jakarta.

[DPU] Departemen Pekerjaan Umum.(2006): Pedoman Konstruksi dan Bangunan. Pekerjaan Tanah Dasar. Badan Penerbit Pekerjaan Umum. Jakarta.

Forsblad, L. (1988): Kompaksi Urugan Tanah dan Batuan dengan Getaran . bina Aksara. Jakarta.

Gill, WR, dan Van den Berg, GE. (1967): Soil Dynamic in Tillage and Traction.USDA Agr. Hand Book.

Road Note 31. (1977): A Guide to the structural design of bitumen-surfacedroads intropical and sub-tropical countries. Transport and Road ResearchLaboratory, Her Majesty's Stationery Office, London, UK.

Robert, D., dan Krebs, W.(1971): Highway materials. McGraw-Hill Book Company.

Saodang, H.(2009): Struktur dan Konstruksi Jalan Raya. Penerbit Nova. Bandung.

Sapei,A., Dhalhar, K., Fuji, S., Miyauchi dan Sudou, S.(1990): Buku Penuntun Pengukuran Sifat Fisik dan Mekanik. Pengembangan Akademik Program Pasca Sarjana. Fakultas Teknologi Pertanian. Institut Pertanian Bogor. Bogor.

Soedarsono, DU. (1979): Konstruksi Jalan Raya. Badan penerbit Pekerjaan Umum.

Sukirman, S. (1999): Perkerasan Lentur Jalan Raya. Penerbit Nova. Bandung.

Terzaghi, K., dan Peck, RB. (1987): Mekanika Tanah dalam Praktek Rekayasa. diterjemahkan oleh Witjaksono, B. Krisna. Erlangga.Jakarta.

Transport Road Research. (1993): A guade to the structural design ofbitumen surfaced roads in tropical and subtropical countries. Transport Research Laboratory Crowthorne. United Kingdom.

Wesley, LD.(1973): Diterjemahkan oleh A.M. Luthfi. Mekanika Tanah. Badan Penerbit Pekerjaan Umum. 